\title{
Digestive enzymes of the anchovy Engraulis capensis in relation to diet
}

\author{
L. J. Seiderer ${ }^{1}$, C. L. Davis ${ }^{1}$, F. T. Robb ${ }^{1} \&$ R. C. Newell ${ }^{2}$ \\ ${ }^{1}$ Department of Microbiology, University of Cape Town, Rondebosch 7700, South Africa \\ ${ }^{2}$ Institute for Marine Environmental Research, Prospect Place, Plymouth PL1 3DH, United Kingdom
}

\begin{abstract}
The anchovy Engraulis capensis (Glch.) is capable of exploiting both diatoms and Crustacea as a food resource. Much of the crustacean exoskeletal material passes into the hindgut after initial disruption in the stomach. Both laminarinase and $\alpha$-amylase activity are relatively low in the oesophagus and stomach, but increase in the caeca and lumen of the intestine. There is no evidence of cellulolytic activity in the gut although numerous gut bacteria occur in the caeca and lumen of the intestine. Distribution of protease activity in the gut follows that of carbohydrases, most proteolytic activity being present in the lumen of the intestine, rather than in the oesophagus or stomach. In contrast, chitinase activity is found early in the digestive pathway and is capable of attacking the chitinous exoskeleton of Crustacea in the stomach, prior to hydrolysis of their contents by carbohydrases and proteases. Bacteria isolated from the intestinal caeca do not hydrolyse chitin, nor do they degrade long-chain polysaccharides or azocasein. Most of the isolates were capable of utilisation of simple sugars commonly found in diatoms and released following hydrolysis of polysaccharides, and also of utilisation of $\mathrm{N}$-acetylglucosamine formed as an endproduct of chitin hydrolysis. Anaerobic strains were, in addition, capable of urea utilisation. Our data thus suggest that digestive enzymes allow E. capensis to exploit a wide range of food items, including diatoms and Crustacea, without bacterial involvement. The gut microflora may be primarily maintained by uptake of the endproducts of carbohydrate, protein and chitin degradation.
\end{abstract}

\section{INTRODUCTION}

There have been several studies of the diet and feeding behaviour of anchovies, which often dominate fisheries catches in upwelling areas. In a laboratory study, Leong \& O'Connell (1969; see also O'Connell 1972) showed that the northern anchovy Engraulis mordax is capable of both filter-feeding on phytoplankton and capture of larger particles, including zooplankton. Loukashkin (1970) and Koslow (1981), working on the same species off southern California, confirmed the occurrence of both filter-feeding behaviour and individual prey capture under natural conditions. They showed that selectivity was a function of size of particles and occurred primarily when large particles were available as a food resource. The anchovy is thus primarily an opportunistic feeder which appears to be capable of exploiting a considerable variety of food resources in the water column (see Angelescu 1982 for feeding of E. anchoita).

Digestive enzymes in anchovies might be expected to reflect the wide dietary range of this fish, although there are apparently few detailed studies on Engraulis spp. and none of the Cape anchovy Engraulis capensis. Stickney \& Shumway (1974) reviewed the occurrence of cellulases in a variety of marine fishes including anchovies, and found that cellulase activity was limited to coastal and estuarine species. Patton et al. (1975) showed that E. mordax and the Jack mackerel Trachurus symmetricus possess a general facility for the hydrolysis of wax esters. More recently, Sargent et al. (1979) investigated the assimilation of the wax esters of zooplankton by herring Clupea harengus.

There have also been a number of studies on the occurrence and role of chitinases in the gut of marine fish, especially in those where arthropods form an important part of the diet (Jeuniaux 1961, Micha et al. 1973, Danulat 1986a, b). Okutani (1966) showed that chitinases of gut bacterial origin, as well as those from the host, were implicated in chitinolytic activity of the fish Lateolabrax capensis. Bacteria are common in the guts of many marine fish (Colwell 1962, Sera et al. 
1974) and have been implicated in both cellulolytic activity (Stickney \& Shumway 1974, Fänge \& Grove 1979 ) as well as in the utilisation of urea (AlbertiniBerhaut \& Vallet, 1971).

The present work was undertaken to determine digestive enzyme activity in relation to diet, and the role of the gut microbiota, in the anchovy Engraulis capensis which is an important component of the pelagic fishery in the Southern Benguela upwelling system off South Africa.

\section{MATERIAL AND METHODS}

Nature of gut contents. Specimens of anchovy Engraulis capensis (Glch.) were collected in February 1986 and frozen at $-20^{\circ} \mathrm{C}$ immediately after capture. At a later date, they were defrosted and dissected into oesophagus, stomach, caeca, intestine and hind intestine. These sections were fixed in $2.5 \%$ glutaraldehyde in phosphate buffer ( $\mathrm{pH} 7.2)$ for $4 \mathrm{~h}$ at $4^{\circ} \mathrm{C}$ and a further $2 \mathrm{~h}$ at $22^{\circ} \mathrm{C}$. The samples were then rinsed in 3 changes of phosphate buffer ( $15 \mathrm{~min}$ each) and left in buffer overnight. There followed a standard graded alcohol dehydration series from $50 \%$ to absolute alcohol. The samples were dried in a Polaron Critical Point Dryer for $3^{1 / 2} \mathrm{~h}$, using liquid $\mathrm{CO}_{2}$ as the transitional fluid. They were mounted on a stub using glue and carbon graphite, and 'cracked' open under the light microscope. Each stub was coated with gold palladium for 6 min at $4 \mathrm{~V}$, and viewed in a Cambridge S 200 seres Scanning Electron Microscope.

Enzyme activities. Collection of material. Engraulis capensis were collected in January 1986 at latitude $32^{\circ} 25^{\prime} 17^{\prime \prime} \mathrm{S}$, longitude $18^{\circ} 15^{\prime} 01^{\prime \prime} \mathrm{E}$. They were immediately placed in aerated aquaria on the research vessel and transported live within $24 \mathrm{~h}$ to the laboratory where they were held for up to $3 \mathrm{~d}$. The fish were actively feeding during this $3 \mathrm{~d}$ period as indicated by observation and presence of food in the gut. Six fish ranging from 104 to $133 \mathrm{~mm}$ (mean $115.6 \mathrm{~mm}$ ) in length and weighing 6.9 to $14 \mathrm{~g}$ (mean $9.76 \mathrm{~g}$ ) wet weight, were selected from the catch and sacrificed. The gut was removed from each of the 6 fish and dissected over ice into 4 categories of pooled tissue: oesophagus, stomach, digestive caeca and intestine. The stomach and the intestine wert: further divided into contents and gut wall. Mean gut pH was 5.8 .

The contents of each of the 6 vessels were homogenised over ice with a glass tissue grinder in $5 \mathrm{ml} 67 \mathrm{mM}$ phosphate buffer pH 6.0 with $150 \mathrm{mM} \mathrm{NaCl}$, centrifuged at $15000 \times \mathrm{g}$ for $10 \mathrm{~min}$ and the supernatant decanted for enzyme assays. All enzyme assays were performed in triplicate. Values for enzyme activity are expressed per $\mathrm{mg}$ protein of cructe homogenate. Pro- tein content was assayed by the method of Lowry et al. (1951).

Enzyme assays. Carbohydrase. Laminarinase was assayed by the method of Jacober et al. (1980) using a substrate of $0.4 \%$ laminarin (Sigma). Aliquots of $250 \mu \mathrm{l}$ enzyme extract which had been suitably diluted with phosphate buffer were added to an equal volume of laminarin and incubated in a shaking water bath at $20^{\circ} \mathrm{C}$ for 0,1 and $3 \mathrm{~h}$. Three replicate tubes were used at each time interval and for each of the 6 extracts. Reducing sugars were measured at $660 \mathrm{~nm}$ using the Nelson-Somogyi method (Nelson 1952). Absorbance values were converted to 'glucose equivalents' using the regression

$$
y=0.03+17.14 x\left(N=25, r^{2}=0.95\right)
$$

where $y=$ absorbance at $660 \mathrm{~nm} ; \mathrm{x}=\mathrm{mg}$ glucose.

The enzyme $\alpha$-amylase was also assayed by the Nelson-Somogyi method using $0.5 \%$ oyster glycogen (Merck) as a substrate. Cellulase was assayed in the same way using $0.1 \%$ carboxymethyl cellulose $(\mathrm{CMC}$; $\mathrm{BDH}$ chemicals) as a substrate.

Chitinase. Chitin substrate was prepared by the method of Reichenbach \& Dworkin (1981). Ten g powdered crab shell chitin (Sigma) was treated with $100 \mathrm{ml}$ cold concentrated $\mathrm{HCl}$ for $1 \mathrm{~h}$. The chitin was then precipitated by pouring the solution into 11 distilled water at $4^{\circ} \mathrm{C}$ whilst stirring vigorously. The precipitate was collected by filtration onto a fibreglass filter (Whatman, GF/C) and dialysed overnight against running tap water The $\mathrm{pH}$ was then adjusted to 7.0 with $1 \mathrm{~N} \mathrm{KOH}$ and the resultant slurry was autoclaved without allowing complete drying.

Aliquots of $250 \mu \mathrm{l}$ of enzyme preparation were added to an equal volume of the chitin slurry $\left(20.3 \mathrm{mg} \mathrm{ml}^{-1}\right.$ dry weight) plus $50 \mu \mathrm{l}$ toluene to inhibit bacterial activity (Okutani 1966) and the mixture incubated in a shaking bath for $0,1,24$ and $96 \mathrm{~h}$ at $20^{\circ} \mathrm{C}$. Three replicate samples were taken at each time interval and were assayed for the chitinase endproduct $\beta-1,4$ linked $\mathrm{N}$-acetylglucosamine (NAG) according to the method of Reissig et al. (1955; see also Monreal \& Reese 1969) using a wavelength of $585 \mathrm{~nm}$

Chitinolytic activity was expressed as mg NAG (Sigma) from the calibration equation:

$$
y=0.06+30.55 x\left(N=11, r^{2}=0.99\right)
$$

where $y=$ absorbance at $585 \mathrm{~nm}$; $\mathrm{x}=\mathrm{mg}$ NAG

Protease. Azocasein (Sigma) (for substrate suitability, see Reimerdes \& Klostermeyer 1976) was made up of $0.5 \%$ in $0.2 \mathrm{M}$ Tris- $\mathrm{HCl} \mathrm{pH} \mathrm{7.8,} \mathrm{and} \mathrm{the} \mathrm{protcase}$ assayed after the method of Long et al. (1981). Then $250 \mu \mathrm{l}$ enzyme was added to $500 \mu \mathrm{l}$ of azocasein substrate and incubated in a shaking water bath at $20^{\circ} \mathrm{C}$ for 0,1 and $3 \mathrm{~h}$. The reaction was stopped by the 
addition of $1 \mathrm{ml} 10 \%$ trichloracetic acid and the vials were held at $5^{\circ} \mathrm{C}$ for $30 \mathrm{~min}$. The precipitate was then sedimented by centrifugation, and $1 \mathrm{ml}$ of the supernatant added to $1 \mathrm{ml} 1 \mathrm{~N} \mathrm{NaOH}$. The acid soluble azopeptides were determined spectrophotometrically at $440 \mathrm{~nm}$ and the results expressed in terms of the equivalent commercial proteinase-K (Merck) activity

Uptake of substrates by bacteria. Caeca from the guts of 5 freshly collected fish were removed and homogenised over ice in $67 \mathrm{mM}$ phosphate buffer pH 6.0 with $150 \mathrm{mM} \mathrm{NaCl}$. Samples of $100 \mu$ l homogenate were then removed with a sterile pipette, spread on seawater agar plates (Seiderer et al. 1984), and incubated at $20^{\circ} \mathrm{C}$ for $72 \mathrm{~h}$. A second series of samples was removed under anaerobic conditions (Forma Scientific Anaerobic System, 1024) and cultured anaerobically at $20^{\circ} \mathrm{C}$ for $72 \mathrm{~h}$. Subsequent studies showed that the isolates were facultative anaerobes. Isolates were restreaked until pure cultures were obtained. Three bacterial isolates from aerobic conditions (Isolates 1 to 3 ) and 3 from anaerobic conditions (Isolates 4 to 6 ) were then used in subsequent assays.

\section{RESULTS AND DISCUSSION}

\section{Nature of gut contents}

Fig. 1 shows scanning electron micrographs of the gut contents of Engraulis capensis. The stomach evjdently contained a wide variety of food items including diatom frustules (Fig. 1a) and copepods (Fig. 1b) as was found by King \& Macleod (1976) and Davies (1957) for this species and Sardinops ocellata. As can be seen from Fig. 1c, the copepod in the stomach had evidently undergone some hydrolysis after initial disruption at an early phase in the digestive tract. However, much of the residual exoskeletons appeared to pass with little further digestion into the hindgut.

This suggests that crustacean exoskeletons may be subject to sufficient digestion to make the interior of the prey available, but are not themselves of significance as a food resource for the fish. In support of this, the $\mathrm{C} / \mathrm{N}$ ratio of zooplankton used in our experiments was $4.17 \pm 0.27$ whilst the value for the stomach contents was $5.54 \pm 0.79$. This value rose to $14.46 \pm$ 1.43 in the intestinal contents suggesting a selective removal of protein during passage through the gut.

As in many other fish, bacteria occurred in the gut of Engraulis capensis (Colwell 1962, Sera et al. 1974, Danulat 1986a), especially in the gut caeca (Fig. 1d) although they were also common in the intestine and hindgut.

\section{Enzyme activities}

\author{
Carbohydrases
}

Table 1 summarises values for the concentration of reducing sugars (mg glucose [mg protein] "), at time zero $\left(\mathrm{T}_{0}\right)$, after $1 \mathrm{~h}\left(\mathrm{~T}_{1}\right)$ and after $3 \mathrm{~h}\left(\mathrm{~T}_{3}\right)$, released by enzymes in homogenates of Engraulis capensis gut material incubated at $20^{\circ} \mathrm{C}$ in the presence of $0.4 \%$ laminarin, $0.5 \%$ oyster glycogen and $0.1 \%$ carboxymethyl cellulose (CMC) as substrates.

It is immediately apparent that there was a marked drop in reducing sugar yield after $1 \mathrm{~h}$ of incubation especially in the material from the caeca and intestine. This suggests that there was microbial uptake of sugars following hydrolysis of laminarin and glycogen in the incubation media, and probably also in the gut itself since these were the sites of dense bacterial communities (Fig. 1). It is also clear that, apart from some initial glucose in the CMC media, there was no evidence of significant cellulolytic activity in the gut of Engraulis capensis. This supports the results of work on other fishes which suggests that cellulases are confined to estuarine and coastal species, where cellulose is likely to occur in the diet (Stickney \& Shumway 1974).

Values for laminarinase, $\alpha$-amylase and cellulase activity ( $\mu \mathrm{g}$ glucose [mg protein $]^{-1} \mathrm{~h}^{-1}$ ) in different parts of the gut of Engraulis capensis are summarised in Table 2. Values have been calculated from the sugar released after $1 \mathrm{~h}$ of incubation at $20^{\circ} \mathrm{C}$ in the presence of $0.4 \%$ laminarin, $0.5 \%$ oyster glycogen and $0.1 \%$ $\mathrm{CMC}$ as substrates. The rates show that laminarinase and $\alpha$-amylase activities were relatively low in the oesophagus and stomach compared with those in the caeca and intestine. This is comparable to the results of Piavaux (1973) for other fish, and suggests that carbohydrate digestion occurs mainly after the food material has passed from the anterior gut and stomach to the intestine.

\section{Protease}

Protease activity in homogenates of different parts of the gut of Engraulis capensis incubated at $20^{\circ} \mathrm{C}$ in the presence of $0.5 \%$ azocasein and sampled at time zero $\left(\mathrm{T}_{0}\right)$, after $1 \mathrm{~h}\left(\mathrm{~T}_{1}\right)$ and after $3 \mathrm{~h}\left(\mathrm{~T}_{3}\right)$ is shown in Table 3. Values are expressed as $\mu \mathrm{g}$-equivalents of proteinase$\mathrm{K}$ per $\mathrm{mg}$ protein in the homogenates. The rate of activity was calculated over the first hour of incubation.

Protease activity was sustained over the whole of the incubation period of $3 \mathrm{~h}$ and there was little evidence of proteolysis in the oesophagus or stomach. Proteoly- 

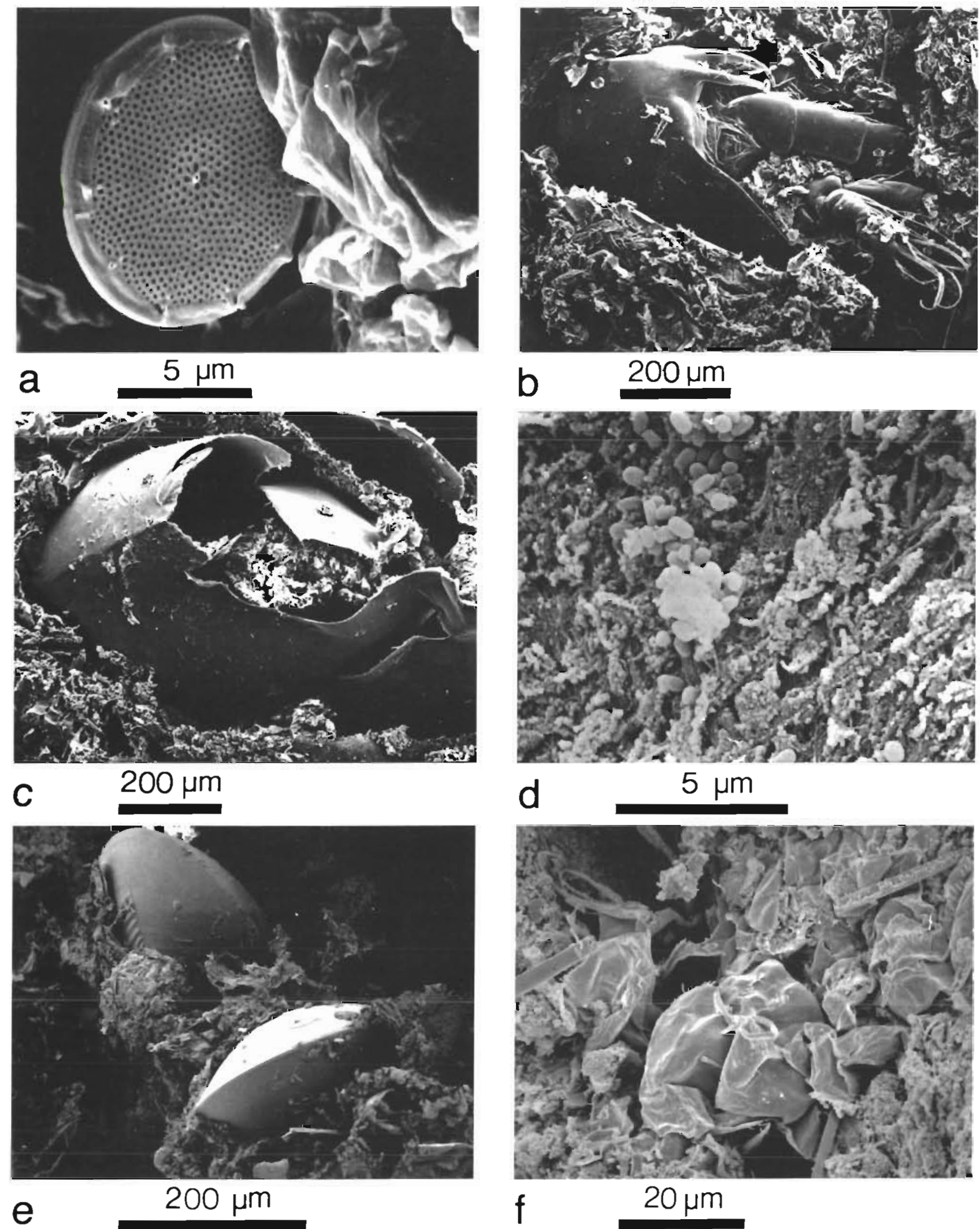

Fig. 1. Engraulis capensis. Scanning electron micrographs of the gut contents of anchovy. (a) Diatom in the stomach. (b) Calanoid copepod in the stomach. (c) Copepod showing breakdown in the stomach. (d) Resident bacteria in the intestinal caeca. (e) Intact bivalves in the hindgut. (f) Copepod exoskeletons in hindgut suggesting chitin does not form a significant resource for the fish 
Table 1. Engraulis capensis. Concentration of reducing sugars (mg glucose [mg protein $]^{-1}$ ) at time zero $\left(T_{i 1}\right)$, after $1 \mathrm{~h}\left(\mathrm{~T}_{1}\right)$ and after $3 \mathrm{~h}\left(\mathrm{~T}_{3}\right)$ released by enzymes in homogenates of gut material incubated at $20^{\circ} \mathrm{C}$ in the presenco of $0.4 \%$ laminarin, $0.5 \%$ oyster glycogen and $0.1 \%$ carboxymethyl cellulose as substrates. Values are means of replicate vessels. Numbers in parentheses: coefficients of variation expressed as percentages

\begin{tabular}{|c|c|c|c|c|c|c|c|c|c|c|}
\hline \multirow[t]{2}{*}{ Source } & \multirow{2}{*}{$\begin{array}{c}\text { Protein } \\
\text { (mg) }\end{array}$} & \multicolumn{3}{|c|}{ Laminarinase } & \multicolumn{3}{|c|}{$\alpha$ - amylase } & \multicolumn{3}{|c|}{ Cellulase } \\
\hline & & $\mathrm{T}_{0}$ & $T_{1}$ & $T_{3}$ & $\mathrm{~T}_{0}$ & $T_{1}$ & $\mathrm{~T}_{3}$ & $T_{0}$ & $T_{1}$ & $T_{3}$ \\
\hline Oesophagus & $0.166(2)$ & $0.030(10)$ & $0.045(7)$ & $0.063(21)$ & $0.056(7)$ & $0.176(3)$ & $0.454(3)$ & 0.045 & 0.000 & 0.000 \\
\hline Stomach & $0.309(0)$ & $0.032(13)$ & $0.096(3)$ & $0.073(8)$ & $0.054(2)$ & $0.327(0)$ & $0.622(1)$ & 0.058 & 0.000 & 0.000 \\
\hline Stomach contents & 0.126 & $0.060(5)$ & $0.117(15)$ & $0.309(4)$ & $0.043(5)$ & $0.132(2)$ & $0.375(6)$ & 0.000 & 0.000 & 0.000 \\
\hline Caeca & $0.386(3)$ & $0.059(2)$ & $0.625(2)$ & $0.696(4)$ & $0.074(0)$ & $0.728(2)$ & $0.729(3)$ & 0.000 & 0.050 & 0.051 \\
\hline Intestine & $0.137(4)$ & $0.071(8)$ & $0.812(3)$ & $1.851(0)$ & $0.054(11)$ & $0.970(6)$ & 1.950 & 0.113 & 0.034 & 0.003 \\
\hline Intestinal contents & $0.293(1)$ & $0.107(5)$ & $0.823(0)$ & $0.904(1)$ & $0.098(2)$ & $0.992(1)$ & $0.955(3)$ & 0.149 & 0.004 & 0.000 \\
\hline
\end{tabular}

Table 2. Engraulis capensis. Carbohydrase activity ( $\mu \mathrm{g}$ glucose [mg protein ${ }^{-1} \mathrm{~h}^{-1}$ ) in different parts of the gut. Values calculated from sugar released after $1 \mathrm{~h}$ of incubation at $20^{\circ} \mathrm{C}$ in the presence of $0.4 \%$ laminarin, $0.5 \%$ oyster glycogen and $0.1 \%$ carboxymethyl cellulose as substrates. Compiled from Table 1

\begin{tabular}{|lccc|}
\hline Source & $\begin{array}{c}\text { Laminari- } \\
\text { nase }\end{array}$ & $\begin{array}{c}\alpha- \\
\text { amylase }\end{array}$ & $\begin{array}{c}\text { Cellu- } \\
\text { lase }\end{array}$ \\
\hline Oesophagus & 15.0 & 120.0 & 0.0 \\
Stomach & 64.0 & 273.0 & 0.0 \\
Stomach contents & 57.0 & 89.0 & 0.0 \\
Caeca & 566.0 & 654.0 & 50.0 \\
Intestine & 741.0 & 916.0 & 0.0 \\
Intestinal contents & 716.0 & 894.0 & 0.0 \\
\hline
\end{tabular}

sis occurred dominantly in the lumen of the intestine (Torrissen 1984).

\section{Chitinase}

In order to utilise Crustacea as a food source, the suite of digestive enzymes of Engraulis capensis would have to include a chitinase, capable of degrading the chitinous exoskeleton before hydrolysis of the internal contents by carbohydrases and proteases.

Table 4 shows the chitinase activity in different parts of the gut of Engraulis capensis in the presence of precipitated crab shell chitin (20.3 $\mathrm{mg} \mathrm{ml}^{-1}$ ) as substrate. Initial experiments with $50 \mu l$ toluene added per $500 \mu \mathrm{l}$ incubation medium at $\mathrm{T}_{0}$ showed $\mathrm{N}$-acetylglucosamine (NAG) release up to $T_{24}$, after which time NAG concentrations fell. This possibly resulted from uptake of NAG by bacteria which developed as toluene was lost from the medium. In all later experiments bacterial activity was inhibited by the addition of $0.1 \%$ toluene every $12 \mathrm{~h}$. Chitinase was evidently present in the oesophagus and stomach, as well as in the intestine. The chitinase activity was, however, relatively low, requiring incubation periods of at least
$24 \mathrm{~h}$ at $20^{\circ} \mathrm{C}$ compared with 1 to $3 \mathrm{~h}$ in the case of laminarinase, $\alpha$-amylase and protease.

Table 5 summarises chitinase activity (mg NAG [mg homogenate protein $]^{-1}$ ) at time zero $\left(\mathrm{T}_{0}\right)$, after $24 \mathrm{~h}$ $\left(\mathrm{T}_{24}\right)$, and after $48 \mathrm{~h}\left(\mathrm{~T}_{48}\right)$ in homogenates of Engraulis capensis gut material incubated at $20^{\circ} \mathrm{C}$ in the presence of whole zooplankton, the composition of which was $82 \%$ copepods, $4.5 \%$ chaetognaths, $4 \%$ amphipods, $6 \%$ euphausiids and $3.5 \%$ other, by numbers ( $34.9 \mathrm{mg}$ dry weight $\mathrm{ml}^{-1}$ ). Unlike carbohydrases and proteases, chitinases were present in the oesophagus and stomach and were capable of hydrolysis of the zooplankton material which forms an important component of the diet. Values of NAG release in the control vessels in which homogenate was replaced by an equal volume of phosphate buffer show, however, that some chitinase activity was associated with the crude zooplankton substrate itself (Jeuniaux \& Amanieu 1955).

The relatively low chitinase activity and its presence in the oesophagus and stomach suggests that the primary role of the chitinases in the gut of Engraulis capensis is associated with initial disruption of ingested Crustacea, rather than as an energy resource for the fish (Alliot 1968; Fig. 1d). Secretion of these enzymes early in the digestive sequence in the oesophagus and stomach permits subsequent hydrolysis of the liberated cell contents by the carbohydrases and proteases which are mainly confined to the intestine.

\section{Uptake of endproducts by gut bacteria}

The utilisation of a variety of substrates by 6 bacterial isolates from the gut caeca was assayed by a combination of standard microbiological assays (Davis 1985) and A.P.I. tests (A.P.I. System, S.A.; La Balme Les Grottes, 38390 Montalieu, Vercieu, France).

Results are summarised in Table 6. These show that none of the bacterial isolates were capable of degrading chitin, complex polysaccharides or protein. 
Table 3. Engraulis capensis. Protease activity expressed as ug-equivalents of proteinase- $K$ (mg protein) ${ }^{-1}$ at time zero ( $\mathrm{T}_{0}$ ), after 1 $\mathrm{h}\left(\mathrm{T}_{1}\right)$ and after $3 \mathrm{~h}\left(\mathrm{~T}_{3}\right)$ in homogenates of different parts of the gut incubated at $20^{\circ} \mathrm{C}$ in the presence of $0.5 \%$ azocasein, in $0.2 \mathrm{M}$ tris $\mathrm{HCl}, \mathrm{pH} 7.8$. Rates $\mathrm{h}^{-1}$ have been calculated from protease activity over the first hour. Homogenate protein data are shown in Table 1. Numbers in parentheses: coefficient of variation expressed as percentages

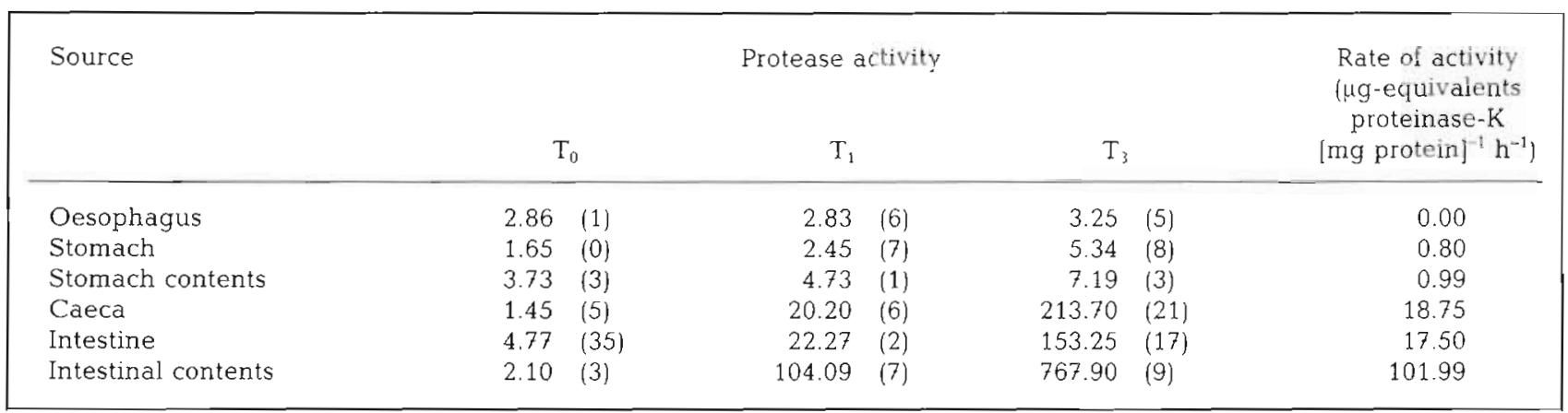

Table 4. Engraulis capensis. Chitinase activity (mg N-acetylglucosamine [mg homogenate protein] ${ }^{-1}$ ) at time zero ( $\mathrm{T}_{n}$ ), after $24 \mathrm{~h}$ $\left(\mathrm{T}_{24}\right)$ and after $96 \mathrm{~h}\left(\mathrm{~T}_{96}\right)$ in homogenates of gut material incubated at $20^{\circ} \mathrm{C}$ in the presence of precipitated crab shell chitin $(20.3$ $\mathrm{mg} \mathrm{ml}^{-1}$ ) substrate. Bacterial activity was inhibited by the addition of $50 \mu \mathrm{l}$ toluene per $500 \mu \mathrm{l}$ incubation medium every $12 \mathrm{~h}$. Homogenate protein data are shown in Table 1

\begin{tabular}{|c|c|c|c|c|}
\hline Source & $T_{0}$ & $\begin{array}{l}\text { mase ac } \\
T_{24}\end{array}$ & $T_{96}$ & $\begin{array}{l}\text { Rate of NAG release ( } \mu \mathrm{g} \\
\left.\qquad[\mathrm{mg} \text { protein }]^{-1} \mathrm{~h}^{-1}\right)\end{array}$ \\
\hline Oesophagus & 0.001 & 0.077 & 0.129 & 3.167 \\
\hline Stomach & 0.000 & 0.040 & 0.080 & 1.667 \\
\hline Stomach contents & 0.000 & 0.118 & 0.253 & 4.917 \\
\hline Caeca & 0.000 & 0.030 & 0.087 & 1.250 \\
\hline Intestine & 0.000 & 0.089 & 0.242 & 3.708 \\
\hline Intestinal contents & 0.006 & 0.159 & 0.273 & 6.625 \\
\hline Blank NAG (mg) & 0.000 & 0.000 & 0.000 & \\
\hline
\end{tabular}

Because bacteria may require the presence of $\mathrm{N}$ acetylglucosamine (NAG) for the induction of chitinase (Monreal \& Reese 1969), traces elements of NAG were added to the chitinase substrate, but the results were also negative (Table 6).

Most of the isolates, especially those cultured under aerobic conditions, were capable of utilising simple sugars (Galli \& Giese 1959, Prim \& Lawrence 1975), as well as NAG formed as an endproduct of chitin hydrolysis. Anaerobic strains were, in addition, capable of exploiting urea as a substrate (AlbertiniBerhaut \& Vallet 1972). In the case of NAG the utilisation rate ( $\mu \mathrm{g} \mathrm{NAG} \mathrm{h}^{-1}$ ) increases with substrate concentration over the range 0.2 to $5.0 \mathrm{mM}$. At substrate concentrations of $0.2,0.5,1.0$ and $5.0 \mathrm{mM} \mathrm{NAG}$, the utilisation rates of isolate No. 6 were $0.1,0.58,0.90$ and $2.5 \mu \mathrm{gAG} \mathrm{h}^{-1}$ respectively.

These data suggest that the gut microflora isolated from the caeca of Engraulis capensis are incapable of direct exploitation of the complex components comprising the ingested food of the anchovy and may be sustained by utilisation of the endproducts of carbo- hydrate, protein and chitin hydrolysis released by the action of fish-derived enzyme activity.

\section{CONCLUSION}

Our results show that the anchovy Engraulis capensis is capable of exploiting both diatoms and Crustacea as a food resource, much as reported for other sardinelike fishes (Lasker 1973, Cushing 1978, Angelescu 1981, 1982). Scanning electron microscopy suggests that much of the exoskeletal material passes through the gut and is not exploited to a major extent. These results are confirmed by $\mathrm{CHN}$-analysis which yielded a value of $4.17 \pm 0.27$ for zooplankton, $5.54 \pm 0.79$ for stomach contents and $14.46 \pm 1.43$ for intestinal contents which suggests selective digestion and absorption of nitrogen.

The major storage product of diatoms is chrysolaminarin (Darley 1977, Myklestad 1978). Both laminarinase and $\alpha$-amylase activity is relatively low in the oesophagus and stomach of Engraulis capensis, 
Table 5. Engraulis capensis. Chitinase activity (mg $\mathrm{N}$-acetylglucosamine [mg homogenate protein] ${ }^{-1}$ ) at time zero ( $\mathrm{T}_{0}$ ), after $24 \mathrm{~h}$ $\left(\mathrm{T}_{24}\right)$ after $48 \mathrm{~h}\left(\mathrm{~T}_{48}\right)$ in homogenates of gut material incubated at $20^{\circ} \mathrm{C}$ in the presence of whole zooplankton substrate $(34.9 \mathrm{mg}$ dry weight $\mathrm{ml}^{-1}$ ). Bacterial activity was inhibited by the addition of $50 \mu \mathrm{l}$ toluene per $500 \mu \mathrm{l}$ incubation medium every $12 \mathrm{~h}$. Blank values represent the mean of vessels in which homogenate was replaced by an equal volumo of phosphate buffer $\mathrm{pH} 6.0$. Numbers in parentheses: coefficients of variation expressed as percentages

\begin{tabular}{|c|c|c|c|c|c|}
\hline Source & Protein (mg) & $\begin{array}{l}\text { Chitinase activity } \\
\qquad \mathrm{T}_{0}\end{array}$ & $\begin{array}{l}\text { Chitinase activity } \\
\qquad \mathrm{T}_{24}\end{array}$ & $\begin{array}{l}\text { Chitinase activity } \\
\qquad \mathrm{T}_{48}\end{array}$ & $\begin{array}{l}\text { Rate of NAG } \\
\text { release }(\mu \mathrm{m}[\mathrm{mg} \\
\text { protein }]^{-1} \mathrm{~h}^{-1}\end{array}$ \\
\hline Oesophagus & 0.467 & 0.037 & 0.134 & 0.224 & 4.042 \\
\hline Stomach & $0.797 \quad$ (11) & 0.036 & 0.083 & 0.117 & 1.958 \\
\hline Stomach contents & 0.370 & 0.085 & 0.197 & 0.266 & 4.667 \\
\hline Caeca & 0.960 & 0.031 & 0.068 & 0.082 & 1.542 \\
\hline Intestine & $0.403 \quad(15)$ & 0.064 & 0.119 & 0.186 & 2.292 \\
\hline Intestinal contents & $0.743 \quad(7)$ & 0.037 & 0.082 & 0.109 & 1.875 \\
\hline Blank NAG (mg) & & 0.027 & 0.040 & 0.069 & \\
\hline
\end{tabular}

Table 6. Substrates utilised by 6 bacterial isolates (Nos. 1 to 6 ) from the gut caeca of the anchovy Engraulis capensis. The isolates are aerobic and anaerobic by isolation only

\begin{tabular}{|c|c|c|c|c|c|c|c|}
\hline \multirow[t]{2}{*}{ Substrate } & \multirow[t]{2}{*}{ Assay ${ }^{1}$} & \multicolumn{3}{|c|}{ Aerobic } & \multicolumn{3}{|c|}{ Anaerobic } \\
\hline & & 1 & 2 & 3 & 4 & 5 & 6 \\
\hline Chitin & $a b$ & - & - & - & - & - & - \\
\hline Chitin + NAG & $\mathrm{b}$ & - & - & - & - & - & - \\
\hline Cellulose & a & - & - & - & - & - & - \\
\hline Starch & a & - & - & - & - & - & - \\
\hline Alginate & $a$ & - & - & - & - & - & - \\
\hline Laminarin & $a b$ & - & - & - & - & - & - \\
\hline Gelatin & $c$ & + & - & - & - & - & - \\
\hline Milk & $\mathrm{a}$ & + & + & + & + & + & + \\
\hline Azocasein & $\mathrm{b}$ & - & - & - & - & - & - \\
\hline Mannitol & c & + & + & + & - & - & - \\
\hline Maltose & c & - & - & - & - & - & - \\
\hline Glucose & c & + & + & + & - & - & - \\
\hline Galactose & c & + & + & + & + & + & + \\
\hline Rhamnose & c & - & - & - & - & - & - \\
\hline Sucrose & c & + & + & + & + & - & + \\
\hline Melibiose & c & - & - & - & - & - & - \\
\hline Arabinose & c & + & + & + & - & - & + \\
\hline Inositol & c & - & - & - & - & - & - \\
\hline Sorbitol & c & - & - & - & - & - & - \\
\hline Amygdalin & $c$ & + & + & + & - & - & - \\
\hline Urea & $c$ & - & - & - & + & + & + \\
\hline $\mathrm{NAG}$ & C & + & + & + & - & - & - \\
\hline \multicolumn{5}{|c|}{$\begin{array}{l}{ }^{1} \mathrm{a}=\text { plate assays } ; \quad \mathrm{b}=\text { liquid assays; } \\
\text { (enteric and non-enteric) }\end{array}$} & \multicolumn{3}{|c|}{$\mathrm{c}=\mathrm{API}$ test } \\
\hline
\end{tabular}

but increases in the intestinal caeca and intestinal contents. This supports the work of Piavaux (1973) for other fish and suggests that carbohydrate digestion occurs mainly after the food material has passed from the anterior gut and stomach into the intestine. There is, however, no evidence of endogenous or bacterially produced cellulolytic activity in the gut of E. capensis, despite the occurrence of numerous gut bacteria. This conforms with data for other fishes which suggest that cellulases are confined to estuarine and coastal species where cellulose is likely to occur in the diet (see Stickney \& Shumway 1974).

The distribution of protease activity in the gut in general follows that of the carbohydrases. There was little evidence of proteolysis in the oesophagus or stomach, proteolytic activity occurring dominantly in the lumen of the intestine (Torrissen 1984). In contrast, chitinase occurs early in the digestive tract and appears to be capable of attacking the chitinous exoskeleton of Crustacea in the stomach, prior to hydrolysis of their internal contents by carbohydrases and proteases.

Bacteria are common in the gut of Engraulis capensis especially in the intestinal caeca and intestinal lumen (Fig. 1). In some other fish, they have been implicated in chitin digestion (Okutani 1966, Goodrich \& Morita 1977 a, b), as well as in cellulolytic activity (Stickney \& Shumway 1974, Fänge \& Grove 1979) and in the utilisation of urea (Albertini-Berhaut \& Vallet 1972). Our study shows that bacteria isolated from the intestinal caeca do not hydrolyse chitin, even in the presence of trace amounts of $\mathrm{N}$-acetylglucosamine (NAG) required by some bacteria for chitinase induction (Monreal \& Reese 1969), nor do they use complex polysaccharides or azocasein directly as a substrate. Most of the isolates, especially those cultured under aerobic conditions, were capable of utilisation of simple sugars which are commonly found in diatoms (Handa 1969) and are released following hydrolysis of polysaccharides. They were also capable of utilisation of the NAG formed as an endproduct of chitin hydrolysis. The anaerobic strains were, in addition, capable of using urea as a substrate (Albertini-Berhaut \& Vallet 1972).

Thus, although bacteria have been implicated in the utilisation of both cellulose and chitin in nearshore and estuarine fishes (Stickney \& Shumway 1974, Goodrich 
\& Morita $1977 \mathrm{a}$, b) whose diet may comprise substantial quantities of detrital material, our data suggest that the 'endogenous' digestive enzymes of the anchovy Engraulis capensis are capable of exploiting a wide range of food items, including diatoms and Crustacea, without bacterial involvement (Bitterlich 1985, Danulat 1986a, b). The gut microflora isolated from the caeca appear to be incapable of direct utilisation of the principal components of the diet of this anchovy, and may be maintained by utilisation of the endproducts of carbohydrate, protein and chitin degradation, released by the action of anchovy enzymes.

Acknowledgements. We are grateful to Mr. A. James and the Department of Sea Fisheries, Roggebaai, South Africa, for the collection of the fish used in this study, and to Mr. K. Schultes and Ms. M. Graham of the E. M. Unit, University of Cape Town, for assistance with scanning electron microscopy. Drs. L. J. Seiderer and C. L. Davis are supported by funds from the South African Council of Oceanographic Research (S.A.N.C.O.R.) to the Benguela Ecology Programme. Dr. R. C. Newell is funded through a Senior Research Fellowship of the Royal Society, London. We thank Mrs. M. Kenmuir and Mrs. G. Wilson for assistance in the preparation of the manuscript

\section{LITERATURE CITED}

Albertini-Berhaut, J., Vallet, F. (1972). Utilisation alimentaire de l'urée chez les muges. Tethys 3 (3): 677-680

Alliot, E. (1968). Absorption intestinale de I'N-acetyl-glucosamine chez la petite Roussette: Scylliorhinus canicula. C. r. Séanc. Soc. Biol. 161: 2544-2546

Angelescu, V. (1981). Trophic ecology of the Anchovy of the Argentinian Continental Shelf (Engraulidae, Engraulis anchoita) Part I. Morphology of the digestive system in relation to feeding. ACTAS VIII Cong. Latinoamer. Zool., Merida, Venezuela 2: 1317-1350

Angelescu, V (1982). Trophic ecology of the Anchovy of the Argentinian Continental Shelf (Engraulidae, Engraulis anchoita) Part II. Feeding behaviour and trophic relationships in the ecosystem. Contrib. Inst. Nac. Invest. des Pesq. 383: 281-298

Bitterlich, G. (1985). Die Emährung des Silberkarpfens (Hypophthalmichthys molitrix). Zur Frage der Stoff- und Energieversorgung sogenannter herbivorer Fische. Ph.D. thesis, Naturwissenschaftliche Fakultät der Leopold-Franzens-Universität in Innsbruck, Austria

Colwell, R. R. (1962). The bacterial flora of Puget Sound fish. J. appl. Bact. 25 (2): 147-158

Cushing, D. H. (1978). Upper trophic levels in upwelling areas. In: Boje, R. Tomczak, M. (ed.) Upwelling ecosystems. Springer-Verlag, Berlin, p. 101-110

Danulat, E. (1986a). The effects of various diets on chitinase and $\beta$-glucosidase activities and the condition of cod, Gadus morhua (L.). J. Fish Biol. 28: 191-197

Danulat, E. (1986b). Role of bacteria with regard to chitin degradation in the digestive tract of the cod Gadus morhua. Mar Biol. 90 (3): 335-344

Darley, W. M. (1977). Biochemical composition. In: Werner D. (ed.) The biology of the diatoms, Botanical Monographs, Vol. 13. Blackwell Scientific Publications, Oxford p. $198-223$
Davies, D. H. (1957). The South African Pilchard, Sardinops ocellata. Preliminary report on feeding off the West Coast, 1953-1956. Div. Fish. Invest. Report S. Afr. 30: 1-40

Davis, C. L. (1985). Physiological and ecological studies of mannitol utilizing marine bacteria. Ph.D. thesis, Univ. of Cape Town, Rondebosch

Fänge, R., Grove, D. (1979). Digestion. In: Hoar, W, S., Randall, D. J. (ed.) Fish physiology, Vol. VIII. Academic Press, New York, p. 161-260

Galli, D. R., Giese, A. C. (1959). Carbohydrate digestion in a herbivorous snail, Tegula funeralis. J. exp. Zool. 140: 415-440

Goodrich, T. D., Morita, R. Y. (1977a). Incidence and estimation of chitinase activity associated with marine fish and other estuarine samples. Mar. Biol. 41: 349-353

Goodrich, T. D., Morita, R. Y. (1977b). Bacterial chitinase in the stomachs of marine fishes from Yaquina Bay, Oregon, USA. Mar. Biol. 41: 355-360

Handa, N. (1969). Carbohydrate metabolism in the marine diatom Skeletonema costatum. Mar. Biol. 4: 208-214

Jacober, L. F., Rice, C., Rand, A. G., Jr. (1980). Characterization of the carbohydrate degrading enzymes in the surf clam crystalline style. J. Food Sci. 45: 381-385

Jeuniaux, C. (1961). Chitinases: an addition to the list of hydrolases in the digestive tract of vertebrates. Nature, Lond. 192: 135-136

Jeuniaux, Ch., Amanieu, M. (1955). Propriétés chitinolytiques du liquide exuvial du ver à soie (Bombyx mori L.). Experientia XI (5): 195-197

King, D. P. F., Macleod, P. R. (1976). Comparison of the food and the filtering mechanisms of the pilchard, Sardinops ocellata, and the anchovy Engraulis capensis, off South West Africa. 1971-1972. Div. Sea Fish. S. Afr. Investig. Rep. 111. 1-29

Koslow, J. A. (1981). Feeding selectivity of schools of Northern Anchovy, Engraulis mordax, in the southern Californian Bight. Fish. Bull. U.S. 79: 131-142

Lasker, R. (1973). Utilization of zooplankton energy by a Pacific sardine population in the California current. In: Steele, J. H. (ed.) Marine food chains. Oliver \& Boyd, Edinburgh, p. 265-284

Leong, R. J. H., O'Connell, C. P. (1969). A laboratory study of particulate and filter feeding of the Northern Anchovy, Engraulis mordax. J. Fish. Res. Bd Can. 26: 557-582

Long, S., Mothibeli, M. A., Robb, F. T., Woods, D. R. (1981). Regulation of extracellular alkaline protease activity by histidine in a collagenolytic Vibrio alginolyticus strain. J. gen. Microbiol. 127. 193-199

Loukashkin, A. S. (1970). On the diet and feeding behaviour of the Northern Anchovy, Engraulis mordax (Girard). Proc Calif. Acad. Sci. 4th Ser. 37 (93): 419-458

Lowry, O. H., Roseborough, N. J., Farr, A. L., Randall, R. N (1951). Protein measurements with the folin phenol reagents. J. biol. Chem. 193: 265-275

Micha, J. C., Dandrifosse, G., Jeuniaux, Ch. (1973). Distribution et localisation tissulaire de la synthese des chitinases chez les vertebres inferieurs. Archs int. Physiol. Blochim. 81: 4.39-451

Monreal, J., Reese, E. T (1969). The chitinase of Serratia marcescens. Can. J. Microbiol. 115: 689-696

Myklestad, S. (1978). B-1,3-Glucans in diatoms and brown seaweeds. In. Hellebust, J. A., Craigie, J. C. (ed.) Handbook of phycological methods, Vol. 2, Physiological and brochemical methods. Cambridge University Press, Cambridge, p. 133-141

Nelson, M. (1952). A photometric adaptation of the Somogyl 
method for the determination of glucose. J. biol. Chem 195: $375-380$

O'Connell, C. P. (1972). The interrelation of biting and filtering in the feeding activity of the Northern Anchovy, Engraulis mordax. J. Fish. Res. Bd Can. 29: 285-293

Okutani, K. (1966). Studies of chitinolytic systems in the digestive tracts of Lateolabrax japonicus. Bull. Misaki mar. biol. Inst. Kyoto Univ. 10: 1-47

Patton, J. S., Nevenzel, J. C., Benson, A. A. (1975). Specificity of digestive lipases in hydrolysis of wax esters and triglycerides studied in Anchovy and other selected fish. Lipids 10 (10): 575-583

Piavaux, A. (1973). Origine non bactérienne de la laminarinase intestinale de Tilapia macrochir Boulenger. Archs int. Physiol. Biochem. 81: 737-743

Prim, P., Lawsence, J. M. (1975). Utilization of marine plants and their constituents by bacteria isolated from the gut of Echinoids (Echinodermata). Mar. Biol. 33: 167-173

Reichenbach, H., Dworkin, M. (1981). The order Myxobacteriales. In: Starr, M. P., Stolp, H., Truper, H. G., Balows, A., Schlegel, H. C. (ed.) The prokaryotes, Vol. I. SpringerVerlag, Berlin, p. 360-376

Reimerdes, E. H., Klostermeyer, H. (1976). Determination of proteolytic activities on casein substrates. In: Colowick, S. P., Kaplan, N. O. (ed.) Methods in enzymology, Vol. XLV.
Proteolytic enzymes, Part B. Academic Press, New York, p. $26-28$

Reissig, J. L., Strominger, J. L., Leloir, L. F. (1955). A modified colorimetric method for the estimation of $\mathrm{N}$-acetylamino sugars. J. biol. Chem. 217: 959-966

Sargent, J. R., McIntosh, R., Bauermeister, A., Blaxter, J. H. S. (1979). Assimilation of the wax esters of marine zooplankton by herring (Clupea harengus) and rainbow trout (Salmo gairdnerii). Mar. Biol. 51: 203-207

Seiderer, L. J., Davis, C. L., Robb, F. T., Newell, R. C. (1984). Utilisation of bacteria as nitrogen resource by kelp-bed mussel Choromytilus meridionalis. Mar. Ecol. Prog. Ser 15: $109-116$

Sera, H., Ishida, Y., Kadota, H. (1974). Bacterial flora in the digestive tracts of marine fish. In: Colwell, R. R., Morita, R. $Y$. (ed.) Effect of the ocean environment on microbial activities. University Park Press, Baltimore, p. 467-490

Stickney, R. R., Shumway, S. E. (1974). Occurrence of cellulase activity in the stomachs of fishes. J. Fish Biol. 6: 779-790

Torrissen, K. R. (1984). Characterization of protease in the digestive tract of Atlantic Salmon (Salmo salar) in comparison with Rainbow trout (Salmo gairdnerii). Comp. Biochem. Physiol. 77 (B): 669-674

This article was submitted to the editor; it was accepted for printing on November 3,1986 